\title{
Chinese Culture Teaching from an Intercultural Communication Perspective
}

\author{
Yulou Liu \\ School of Languages and Literature \\ Harbin Institute of Technology, Weihai \\ Weihai, P.R.China
}

\author{
Xiangyu Jiang \\ School of Languages and Literature \\ Harbin Institute of Technology, Weihai \\ Weihai, P.R.China
}

\author{
Xianwei Li \\ School of Languages and Literature \\ Harbin Institute of Technology, Weihai \\ Weihai, P.R.China
}

\begin{abstract}
Communications between countries all over the world are becoming more and more frequent, and cultural exchanges are an indispensable component. Traditional Chinese culture teaching stresses the input of cultural facts, and then it is difficult to be transformed into intercultural communication competence. From an intercultural communication perspective, the paper studies the teaching establishment and arrangement of Chinese culture in college classroom in English from the four following aspects: the teaching objective, the teaching material, the teaching method and teachers, providing some constructive advice and suggestions for the related course teaching.
\end{abstract}

Keywords-Chinese culture teaching; intercultural communication; general education

\section{INTRODUCTION}

Since the $18^{\text {th }}$ National Congress of the Communist Party of China (CPC) and two sessions (National People's Congress and Chinese People's Political Consultative Conference), the state has emphasized that "the cultural soft power of the nation need be improved", "the cultural fields open to the outside world need be enlarged", and that "the foreign cultural exchange need be expanded" [1]. At the same time, the Chinese state has implemented a series of measures centering on how to improve cultural soft power, how to expand foreign cultural exchange and how to have a say in the international world. Chinese President Xi Jinping has delivered important speeches, stressing the significance and urgency for Chinese culture to go outside and meanwhile talking about the means and the objective. In 2017, Opinions on the Implementation of the Inheritance and Development of Fine Traditional Chinese Culture (hereinafter referred to as the "Opinions") released by the General Office of the

This article is sponsored by the MOE (Ministry of Education in China) Project of Humanities and Social Sciences Youth Foundation (17YJC740032), the Teaching and research program youth special program (ITIA 10002010), and School of Languages and Literature, teaching and research program (YYWX201719) of Harbin Institute of Technology, Weihai.
CPC Central Committee and the General Office of the State Council encompasses the very essential task involved: to push forward the communication and appreciation between different cultures; to enhance cultural cooperation, innovate communication ways between various cultures, enrich its content and constantly increase its exchange levels; to strengthen cultural communication and cooperation between the countries along the Belt and Road (the Silk Road Economic Belt and the 21st-Century Maritime Silk Road as its full name); to encourage the development of international cultural trade, thus making more competitive cultural products representing the characteristics of Chinese culture go outside into the international market [2]. From these conferences and policies, it is easy to know that China is paying more and more attention to cultural exchanges with other countries, and encouraging Chinese culture to "go abroad". In international communication and cooperation between China and other countries, the cooperation among universities and institutions of higher education is an integral part. In this way, it has become a heated topic as how to arouse the cultural awareness of Chinese college students in their campus life, and therefore to actively spread Chinese culture in intercultural communication.

From an intercultural communication perspective, based on "Chinese culture teaching" in the college classrooms, the paper inquiries into the problems existing in its teaching process and provides suggestions and references for the future culture teaching.

\section{INTERCULTURAL COMMUNICATION}

Since the $20^{\text {th }}$ century, there has been ground-breaking progress in the development of human science and technology, which has greatly changed the pattern of the world and the life style of the humankind. Among all the inventions, the wide-spread use of computers and the birth of the internet have enabled the human beings to break through the limitations of the living space in the past. One focus of these great changes is that the temporal and spatial distance 
between one person and another has been narrowed. In this way, the tremendously big earth has been compressed into a small "village". Together with this, the global economic integration has speeded up, and the whole world has become much more diversified. No matter it is interaction between people or economic cooperation between countries, it couldn't do without communication. Because of different historical origins and various social customs, all the countries and nationalities on the earth have formed their own specific cultural backgrounds, and these specified cultural backgrounds give birth to differing attitudes towards value, ways of thinking, social conventions and pragmatic regulations. All these factors combined bring about potential barriers for communications.

In this circumstance, intercultural communication has emerged because of demand as a new boundary science, referring to message transmission or cultural exchange activities between individuals and organizations, nations and social groups from different cultural systems. It can also be employed to refer to communication between people with differing language and culture backgrounds. In this way, what needs to be paid attention to and how to communicate properly in foreign exchanges have become the main content for intercultural communication.

There is a broad sense and a narrow sense for intercultural communication. From a narrower sense, intercultural communication refers to the communication between native speakers and non-native speakers. On the other hand, from a broader sense, it can be used to mean communications between people from various cultural backgrounds in a specified context. In this process, language, culture and society are important factors influencing communication between people. And the communication process also involves language conventions and culture conventions as well.

\section{CUlture AND Chinese CUlture}

\section{A. Culture}

The unique culture one person owns is largely decided by the cultural environment he lives in. That's to say, culture is not born with, but acquired later on. Culture has following characteristics:

- Sociality. Culture is the product formed by human beings through their creative activities, playing an essential role in an individual's growth. At the same time, culture does not belong to one special individual, but it is recognized and possessed by the majority members of a group.

- Historicity. Culture is a historical phenomenon, and it is a sedimentary deposit of a specified social development history. People of one generation constantly develop the useful and discard the useless aspect, update it while inheriting the existing culture.

- Nationality. The cultural content is expressed by national forms, mirroring bright national color. Cultures vary from nationality to nationality. Even in the same nationality, culture can be different because of difference in time and geographical locations, thus forming regional difference in the culture.

The culture structure can be divided into three levels: material culture, institution culture and spirit culture. Material culture refers to all the material products created by people in their material production activities, and techniques, skills and methods employed in the process of production. Institution culture means the whole regulation system established by people to regulate and control certain social relationships. Spirit culture has another name of ideational culture, with psychology, concepts and theories as its existing forms. It includes two parts:

- Culture mind-set, culture psychology, culture mentality, culture thought and culture belief deeply rooted in the heart of people;

- The ideological and theoretical system that has been theorized and objectified, in another way, objectified ideas.

\section{B. Chinese Culture}

With Huaxia civilization as its basis, Chinese culture came into being by fully integrating culture ingredients from all regions and all nationalities throughout China. Chinese culture has influenced Japan and the Korean Peninsula a lot, and also has exerted far-reaching influence on Southeast Asian countries such as Vietnam, Singapore, South Asian countries, and even Pan American Region. In recent years, China is becoming stronger and stronger and its international status has been improved. Therefore, Chinese culture has gained more and more recognition and thus been highly valued by countries all over the world including Asian countries and European countries. During the 13th collective study of the Political Bureau of the Central Committee of the $\mathrm{CPC}, \mathrm{Xi}$ Jinping mentioned that Chinese culture is the crystallization of wisdom of the Huaxia nationality in the long history of practice. It can date back to the earliest time in the human history, expressing the deepest spiritual pursuit of the Chinese nation, and at the same time, it represents the unique spiritual mark of the Chinese nation [3]. In this sense, it is a historic responsibility that cannot be relinquished to push forward Chinese culture to the outside world, thus enabling the whole world to have a deeper understanding of China.

Chinese culture is a large and complicated system, covering every aspect of China, such as, political system, the hundred schools of thought, religion and philosophy, literature, music and traditional instrument, traditional festivals and customs, arts, traditional Chinese medicine and martial arts, clothing and adornments, culinary culture (including tea culture and wine culture), architecture and so on. In the specific teaching arrangement, it is advised to choose reading materials from more than one perspectives and dimensions, centering on one core subject. It is better to combine main points with intensive explanation and general extensive clarification together, introducing Chinese culture as comprehensively as possible and providing references as 
well. In this way, the college students can further their study in class according to their own interests after class.

\section{Chinese Culture TEACHING FROM AN INTERCULTURAL COMMUNICATION PERSPECTIVE}

It has become an irreversible trend for Chinese culture to go into the international world. In international communications, it will become their important mission for Chinese college students to introduce Chinese culture in English and make intercultural communications. In intercultural communications, the language, as a very special cultural phenomenon, is a tool of communication and is also an essential carrier of culture. As a consequence, in the process of teaching Chinese culture, it will help a lot for Chinese culture to "go abroad" when the English language is made use of and the Chinese college students are equipped with English expressions of their own native culture.

From an intercultural communication perspective, to learn Chinese culture in English does not mean that the English language is employed to serve cultural communication. On the contrary, Chinese college students can experience Chinese culture in the English language study, thus strengthening their cultural awareness, making them notice cultural communication hidden behind the language learning and improving their language communication competence in their future international communications.

The following briefly outlines Chinese culture teaching system from an intercultural communication perspective from four aspects: the teaching objective, the teaching material, the teaching method and the teachers.

\section{A. The Teaching Objective: to Cultivate Export Competence of Chinese Culture in the Intercultural Context}

In the present national and international contexts, in the stage of college life, social cultural knowledge and cultural experience has gained increasingly more and more prominent position. In this circumstance, it is beneficial for college students to pay more attention to culture learning and culture communication.

From the first day of birth, the Chinese students have been immersed in the large environment of Chinese culture. The family has cultivated their cultural essence and the schools have taught them culture knowledge. In the long process of their growth, the Chinese students have already mastered Chinese culture knowledge to a certain degree, consciously or unconsciously. When it comes to the stage of college life, the students should be familiarized with Chinese culture in a systematic way and have the capability to probe into the cultural factors hidden behind their all kinds of expressions on the surface. At the same time, the Chinese students have been learning English for more than ten years when they go to universities. After so many years of study, the college students have grasped the basic knowledge of the English language, and have had some understanding of cultures in English-speaking countries (here mainly referring to the UK and the USA), and they are able to express themselves in English relatively fluently. In this sense, college students are capable of making a conscious comparison between Chinese culture and English cultures, thus furthering their comprehension of their own culture. Also in the process of intercultural communication, the college students are much more concerned with cultural differences and have the initiative to export Chinese culture. They also lay emphasis on the cultural foundation and the cultural essence of the cross-language understanding, then making communication more practical and effective.

\section{B. The Teaching Material: Integration of Culture Knowledge and Language Competence}

From childhood, Chinese culture in class has always focused on literature works in the history. For other aspects involved in Chinese culture, students' understanding mainly comes from their daily contact with it outside the classroom. Their knowledge, in this way, has not been acquired in a systematic and logical way. As a consequence, the Chinese college students need systematically study Chinese culture consciously. In the meantime, they can take advantage of their English language competence, combining English they have been learning all these years and the Chinese culture, and in the end arriving at expressing Chinese culture in English.

From this angle, the following aspects need to be taken into consideration when the teaching material is determined: 1) the Chinese culture teaching needs to be systematic and comprehensive. Chinese cultural aspects are organized logically and rationally and the learning materials are expanded around the representative topics, such as, political system, the hundred schools of thought, religion and philosophy, literature, music and traditional instrument, traditional festivals and customs, arts, traditional Chinese medicine and martial arts, clothing and adornments, culinary culture (including tea culture and wine culture), architecture and so on. Every chapter focuses on one specific cultural topic, covering language materials of different levels and assigning learning tasks with varying degrees of difficulties. 2) Chinese culture materials need be diversified. The materials can be chosen from papers and digests, classical paragraphs, academic articles, literature classics and so on. 3 ) Chinese culture contexts need be authentic and real. Real life contexts can integrate class learning and real lives, stimulating the students' motivation to study and research. As a consequence, when the students are confronted with real social situations, they can apply what they have learned into practice and improve their communication effect. In the present day, the teaching methods are colorful, and representation ways, for instance, words, pictures, audios and videos, can be employed in the teaching process.

\section{The Teaching Method: Integration of Chinese Culture Teaching and English Language Teaching}

In the present college classroom, the teaching methods are diversified. The basic teaching methods are:

- Instillation. It is mainly about culture explanation, inputting culture knowledge into the students. 
- Comparative teaching. It is mainly about comparing the differences between Chinese culture and Britain, American cultures. The comparative teaching method engages the students in active awareness of the differences between cultures, thus comprehending cultural differences, which is the basic method of intercultural teaching.

- Experimental approach. This teaching method emphasizes experimental teaching, activity teaching, and situational teaching. The multi-media approach, such as audios, videos, can be employed to create all kinds of circumstances for students to be immersed in various cultural contexts, experiencing different cultural roles.

Chinese culture teaching must be together with the English language teaching. In interpreting Chinese culture, it is not only enlarging the students' cultural knowledge, but also introducing the corresponding English expression, which is the foundation of the whole teaching procedures. In the second place, it is very essential to choose and arrange cultural topics, which is helpful to expanding the students' knowledge and broadening their horizon. In this process, the students can also improve their cultural awareness with their self-study. What's more, the comparative way of teaching culture needs to be adopted in teaching, which can deepen the students' impression by comparing the similarities and differences between Chinese culture and Britain/ American culture. In the last place, the difficulty of teaching materials needs to be taken into consideration. It is relatively easier for the Chinese students to read books related to culture in Chinese. When the language is translated into English, the translation needs to be correct and faithful, and be graceful and fluent as well. The teachers have to lay emphasis on the language expression in the translated texts, thus helping the students better understand the carrier - the language.

\section{The Teachers: to Possess Chinese Culture Essence and English Language Competence}

Teaching Chinese culture by using the English language is a great challenge for the English teachers. It requires the teachers to have deep love for, and to have good mastery of the Chinese culture. At the same time, it requires them to have excellent command of the English language. That's to say, the teachers possess a higher proficiency of the English language and are capable of talking about all aspects of Chinese culture in English freely. The teachers are advised to be open-minded, ready to read, research and compare. Put it another way, teaching Chinese culture in English poses a much stricter demand for the teachers in the following aspects: cultural awareness, culture knowledge, culture essence, culture comparison perspective, the English language competence, culture communication competence and so on. To a certain degree, the teachers are required to improve their own culture essence and intercultural communication capabilities, to master effective methods of language teaching, and to integrate the Chinese culture and the English language perfectly.

\section{CONCLUSION}

Communications between countries all over the world are becoming more and more frequent. There is a wide variety of communication and cooperation projects between China and other countries in the world, among which cultural exchanges are an indispensable component. Culture is one essential ingredient of a nation's soft power. It is an issue of urgency as to how the Chinese culture "goes abroad" on the international stage radiating its unique charm. In the intercultural communication, Chinese college students are the main strength in the process of pushing the Chinese culture outside. As a consequence, it is an obligation to broaden the teaching fields in the college classroom and then Chinese college students are able to gain a deeper understanding of the Chinese culture and to improve their pride of their own culture. Therefore, when it comes to Chinese culture teaching in English from an intercultural communication perspective, the following aspects needs to be taken into account, including the teaching objective, the teaching material, the teaching method and the teachers. In the meanwhile, it is better to improve their English competence and intercultural communication capabilities, thus laying a good and solid foundation for them to spread the Chinese culture actively when there is a chance in their later life and work.

\section{REFERENCES}

[1] http://lianghui.people.com.cn/2017/n1/2017/0316/c410899_ 29150065-2.htm

[2] http://news.xinhuanet.com/politics/2017-01/25/c_1120383155.htm

[3] http://news.xinhuanet.com/2012-11/19/c_123967017.htm

[4] X. Y. Bao. Exploration of the Translation Model of Chinese Culture Going Abroad - An Interview with Huang Youyi, Deputy director general and editor in chief of China foreign languages Bureau [J]. Chinese Translators Journal, 2013 (5): 62-65.

[5] W. H. Huang. An Empirical Study on Process Culture Teaching and Intercultural Communicative Competence Cultivation [J]. Journal of PLA University of Foreign Languages, 2015 (1): 51-58.

[6] W. R. Li. External Approaches to Chinese Culture Going AbroadWith Special Reference to International Impacts of Chinese Culture [J]. Chinese Culture Research, 2015 (Autumn Volume): 29-46.

[7] X. H Liu. Intercultural Communicative Competence and it Cultivation: From an Constructive perspective [J]. Foreign Languages and Their Teaching, 2003(1): 34-36.

[8] A. P. Mo, F. Mo. Intercultural Communication: Theory and Practice [M]. Beijing: Peking University Press. 2016.

[9] W. M. Lustig, J. Koester. Intercultural Competence: Interpersona Communication across Cultures (Fifth Edition) [M]. Shanghai: Shanghai Foreign Language Education Press. 2007.

[10] L. L. Qin, W. D. Dai. A Study on Intercultural Communication Courses Oriented to Develop Multicultural Awareness [J]. Computerassisted Foreign Language Education, 2013 (11): 56-65.

[11] X. L. Qu. College English Teaching from an Intercultural Communication Perspective [J]. Journal of Capital Normal University (Social Sciences Edition), 2012 (3): 102-105.

[12] H. L. Zhang, Intercultural Approaches to Foreign Language Teaching. Shanghai, China: Shanghai Foreign Langauge Education Press, and Assessing intercultural Communicative Competence. Clevedon: Multilingual Matters, 1997.

[13] D. F. Shu. Readings in Chinese Culture [M]. Shanghai: Shanghai Foreign Language Education Press. 2016. 
[14] B. W. Gudykunst. Theorizing about Intercultural Communication [M]. Shanghai: Shanghai Foreign Language Education Press. 2014.

[15] Q. C. Yang. The beginning and Exploration of Chinese Culture Going Abroad - A brief Review on the Chinese Academic Translation Projects Sponsored by the National Social Science Fund [J]. Chinese Translators Journal, 2014 (4): 5-7.

[16] D. H. Zheng. Chinese Culture Going Abroad and the Translation of Culture-loaded Words [J]. Shanghai Journal of Translators, 2016 (2): 53-56. 